\title{
Fossil Decapod Crustaceans
}

\section{Crustacés décapodes fossiles}

\author{
Sylvain Charbonnier ${ }^{1, *}$
}

Muséum national d'Histoire naturelle, Paris, Centre de recherche sur la paléobiodiversité et les paléoenvironnements (CR2P, UMR 7207), Sorbonne universités, MNHN, UPMC, CNRS, 57 rue Cuvier, 75005 Paris, France

This thematic issue of the BSGF-Earth Sciences Bulletin is linked to the 6th Symposium on Mesozoic and Cenozoic Decapod Crustaceans. This scientific meeting was held on June 2016 at the Paléospace Museum of Villers-sur-Mer, Normandy, France. It was supported by the French Geological Society (SGF), the Center for Research on Palaeobiodiversity and Palaeoenvironments (UMR 7207 CNRS) and the National Museum of Natural History, Paris (MNHN).

The organization of a symposium dedicated to the Mesozoic and Cenozoic decapod crustaceans was new for France, but was based on a long standing tradition, which dates back to the pioneer work of Latreille, Desmarest and Milne Edwards. During the meeting, nine sessions were proposed and grouped 25 oral communications and 11 posters. Our esteemed colleague Rodney M. Feldmann (Kent State University) opened the scientific sessions with a talk about the Recent Revolution in Decapod Paleontology and concluded that recent remarkable advances have been the result of an increase in the number of palaeontologists devoted to the study of the decapods. Their efforts, coupled with increasingly sophisticated research promises even more innovations in the future.

This special issue groups nine original articles on the main topics discussed during the meeting on the crustaceans: systematics, taxonomy, phylogeny, evolution, palaeoecology, palaeobiology, palaeoenvironment, and palaeobiogeography.

For instance, Hyžný et al. (2017) present a review of the burrowing lobster Axius (Axiidea) in the fossil record with notes on its palaeobiogeography. Regarding the palaeoenvironments, a comparative analysis of the Ypresian crustaceans from the coral-algal environments in north-eastern Italy, and a study on the faunal turnovers in the context of the Mesozoic and Cenozoic evolution of the Basque-Cantabrian Basin (Spain), are proposed by Beschin et al. (2017) and LópezHorgue and Bodego (2017) respectively. The systematic palaeontology groups different scientific papers about erymid

\footnotetext{
${ }^{1}$ President of the French Geological Society-Guest Editor.

*Corresponding author: scharbonnier@mnhn.fr
}

lobsters (Devillez and Charbonnier, 2017), spiny lobsters (Krobicki and Fraaije, 2017), paguroids (Fraaije et al., 2017a), anomurans (Fraaije et al., 2017b), and the enigmatic thylacocephalans (Charbonnier et al., 2017). In the end, Haug and Haug (2017) propose a reflexion about the species, populations and morphotypes through time with future challenges and possible concepts.

In conclusion, all these articles constitute a small contribution to the edifice of the Decapod Palaeontology.

\section{References}

Beschin C, Busulini A, Calvagno M, Tessier G, Zorzin R. 2017. Ypresian Decapod Crustacean faunas from the coral-algal environments in the Eastern Lessini Mountains (Vicenza and Verona territory-NE Italy): a comparative analysis. In: Charbonnier S, ed. Fossil Decapod Crustaceans. Bull. Soc. géol. Fr., thematic issue 188: 13.

Charbonnier S, Teruzzi G, Audo D, Lasseron M, Haug C, Haug JT. 2017. New thylacocephalans from the Cretaceous Lagerstätten of Lebanon. In: Charbonnier S, ed. Fossil Decapod Crustaceans. Bull. Soc. géol. Fr., thematic issue 188: 19.

Devillez J, Charbonnier S. 2017. The genus Eryma Meyer, 1840 (Crustacea: Decapoda: Erymidae): new synonyms, systematic and stratigraphic implications. In: Charbonnier S, ed. Fossil Decapod Crustaceans. Bull. Soc. géol. Fr., thematic issue 188: 15.

Fraaije RHB, Van Bakel BWM, Jagt JWM. 2017a. A new paguroid from the type Maastrichtian (upper Cretaceous, the Netherlands) and erection of a new family. In: Charbonnier S, ed. Fossil Decapod Crustaceans. Bull. Soc. géol. Fr., thematic issue 188: 17.

Fraaije RHB, D'Arpa C, Van Bakel BWM, Jagt JWM, Zarcone G. 2017b. The Gemmellaro Collection: first record of an anomuran from the Tithonian of Sicily, Italy. In: Charbonnier S, ed. Fossil Decapod Crustaceans. Bull. Soc. géol. Fr., thematic issue, 188: 18.

Haug JT Haug C. 2017. Species, populations and morphotypes through time - challenges and possible concepts. In: Charbonnier S, ed. Fossil Decapod Crustaceans. Bull. Soc. géol. Fr., thematic issue, 188: 20.

Hyžný M, Jakobsen SL, Fraaije RHB. 2017. Reappraisal of the burrowing lobster Axius (Malacostraca: Decapoda: Axiidea) in the fossil record with notes on palaeobiogeography and description of a 
new species. In: Charbonnier S, ed. Fossil Decapod Crustaceans. Bull. Soc. géol. Fr., thematic issue, 188: 12.

Krobicki M, Fraaije RHB. 2017. A new spiny lobster from the upper Jurassic Štramberk-type limestones of Inwałd, Andrychów Klippen, southern Poland. In: Charbonnier S, ed. Fossil Decapod Crustaceans. Bull. Soc. géol. Fr., thematic issue 188: 16.
López-Horgue MA, Bodego A. 2017. Mesozoic and Cenozoic record of decapod crustaceans in the Basque-Cantabrian Basin (Western Pyrenees): new occurrences and faunal turnovers in the context of the basin evolution. In: Charbonnier S, ed. Fossil Decapod Crustaceans. Bull. Soc. géol. Fr., thematic issue 188: 14.

Cite this article as: Charbonnier S. 2017. Fossil Decapod Crustaceans, Bull. Soc. géol. Fr. 188: E2. 